Rev. Latinoam. Psicopat. Fund., São Paulo, v. 11, n. 3, p. 514-516, setembro 2008

\title{
Um companheiro de leituras
}

Guilherme Gutman

Ao olharmos com alguma distância reflexiva, a nossa trajetória intelectual, somos todos capazes de reconhecer a força e o efeito exercidos sobre nós por certos livros, filmes, aulas ou conversas. No caso dos livros - e de textos curtos, como o são os artigos acadêmicos - a sua importância pode se dar por razões diferentes. Às vezes são importantes porque impulsionam o leitor ao trabalho de colocar o novo texto em diálogo com o que se havia lido até então. Em outros momentos, um artigo pode ajudar a "arrumar a casa", isto é, pode ser útil ao dar organicidade e articulação ao nosso corpo de conhecimentos sobre um dado assunto. Em oposição, alguns textos parecem ter o seu maior mérito na desconcertante e salutar função de "bagunçar o coreto", ou seja, na capacidade de deslocar conceitos, de incomodar "verdades terminais" - para utilizar a expressão de Michel Foucault - e de, novamente, pôr o leitor a trabalhar.

Há, também, momentos muito especiais no encontro com certos autores; momentos que - se não são exatamente a tônica de uma vida pautada pelo hábito da leitura - quando surgem, iluminam de tal modo um determinado caminho teórico que, então, já não saberíamos conceber a nossa própria trajetória sem a sua ocorrência. É nessa linha, que Bruno Bettelheim (1991) escreve: 
Embora muitos livros tenham causado forte impressão em meu pensamento, apenas uns poucos mudaram o meu cerne. Ao ler tais livros, experimentei o que Edmund Wilson descreve com tanta propriedade como "choque de reconhecimento", porque me esclareceram quais eram os meus problemas mais prementes (à época) na busca do meu caminho de vida. (...) Alguns eram grandes livros, outros não, nem como obras literárias, nem como conteúdo. Acontece que a circunstância de me familiarizar com esses livros em determinados momentos da vida assumiu os contornos de uma revelação - de uma visão nova que organizava um pouco o meu mundo interior onde antes havia grande certeza e confusão, se não um caos total. (p. 93-4)

Outros livros não são exatamente responsáveis por "revelações" ou por "epifanias" como as que parece ter experimentado Bettelheim. Mas, em contraponto, são "bons amigos" - companheiros de viagem de toda uma vida. É o que notou Sergio Paulo Rouanet (2003) na essência da resposta dada por Freud ao pedido de Hugo Heller - um livreiro e primeiro editor de Imago e da Internationale Zeitschrift fur Psychoanalyse - de que indicasse "dez bons livros". Escreve Freud (1906):

Os senhores me pedem que lhes nomeie "dez bons livros" e recusam-se a acrescentar qualquer palavra esclarecedora. Então, não só me deixam livre para escolher os livros, como para interpretar a demanda que me dirigem. Habituado a prestar atenção a pequenos indícios, não posso deixar de me ater ao texto que traz esse enigmático pedido. Os senhores não dizem "as dez maiores obras" (da literatura universal) (...) Tampouco "os dez livros mais importantes" (...) Nem sequer perguntaram pelos "livros prediletos" (...) Portanto, opino que no texto dos senhores, um particular acento recai sobre a palavra "bom", e com esse predicado entendem designar livros com os quais alguém se sinta como em companhia de "bons" amigos, aos quais se deva parte de seu conhecimento sobre a vida e de sua própria concepção do mundo. (p. 223)

Naturalmente, não se espera de uma seção de resenha de artigos, que tenha nem o caráter de um encontro extraordinário como os referidos por Bettelheim nem o valor dos "dez bons amigos de Freud". Todavia, não deixaremos de alimentar a esperança de que - para o leitor da Revista Latinoamericana de Psicopatologia Fundamental, esta seção possa funcionar como "um bom colega de profissão e de interesses"; útil, por exemplo, na escolha do que ler e do que não ler, em tempos de volumes inabordáveis de artigos e periódicos à disposição, em relação aos quais, facilmente, o leitor poderia se ver navegando em calmarias inócuas, ou por mares menos gentis.

Vale notar que seria um erro - ou simples presunção - imaginar que à pergunta - "O que ler, quando há tanto para ler, e quando se sabe que não será possível ler tudo?" - caberia propor um regime programático de leituras 
pré-determinadas. Na verdade, a tarefa principal dessa seção - tarefa tornada ainda maior pela boa condução dada a ela até então pelo dr. Mário Eduardo Costa Pereira - é a de convocar o leitor a participar do jogo: experimentem os textos, lancem-se ao risco, inerente à leitura, que é o de interpretar, o de refletir e o de elaborar o que foi lido.

Comporá a seção de resenhas um comentário no qual se procurará apresentar e encadear três ou quatro artigos publicados em revistas nacionais e internacionais. Obviamente os artigos serão escolhidos em função da importância dos veículos, da qualidade de seus autores e da pertinência do conteúdo para o foco da Revista, podendo ser reunidos, a cada trimestre, em torno de um tema comum.

$\mathrm{Na}$ edição de dezembro começamos. Até lá!

\section{Referências}

Bettelneim, B. A Viena de Freud e outros ensaios. Rio de Janeiro: Campus, 1991.

Freud, S. (1906). Respuesta a una encuesta "Sobre la lectura y los buenos libros. In: Obras Completas. Buenos Aires: Amorrortu, 1993. v. IX.

Rouanet, S. P. Os dez amigos de Freud. São Paulo: Companhia das Letras, 2003.

\section{GuLHerme GutMan}

Psiquiatra e psicanalista, professor adjunto do departamento de psicologia da Pontifícia Universidade Católica do Rio de Janeiro - PUC-Rio (Rio de Janeiro, RJ, Brasil).

Rua Visconde de Pirajá, 82/704 - Ipanema

22410-000 Rio de Janeiro, RJ - Brasil

Fone: (21) 2523-8344

e-mail: guilhermegutman@gmail.com 